[Transaction ]

\title{
Development of Bi-directional Grading Method for Uniform Easy-order System -Focused on Blouse for Adult Female-
}

\author{
Young Lim Choi $\cdot$ Yun Ja Nam* ${ }^{\dagger} \cdot$ Kueng Mi Choi** \\ Dept. of Clothing \& Textiles, Seoul National University \\ *Dept. of Clothing \& Textiles, Seoul National University \\ /Research Institute of Human Ecology, Seoul National University \\ **Dept. of Fashion Design, Dong Seoul College
}

Received March 3, 2009; Revised (April 7, 2009; April 28, 2009); Accepted May 6, 2009

\author{
유니폼의 이지오더 시스템을 위한 양방향 그레이딩 깨발 \\ -성인여성 블라우스를 중심으로- \\ 최영림 · 남윤자** 최경미** \\ 서울대학교 의류학과, *서울대학교 의류학과/생활과학연구소, **동서울대학 패션디자인과 \\ 접수일(2009년 3월 3일), 수정일(1차 : 2009년 4월 7일, 완료일 : 2009년 4월 28일), 게재확정일(2009년 5월 6일)
}

\begin{abstract}
To provide adequate fit for women over a range of sizes, the grading process should reflect their body dimensions. Current methods of creating sized garments are not addressing the need for a good or even an adequate fit for the easy-order system. This study suggests a grading rule allocating system that can improve the appropriateness of clothing for uniform easy-order system. Also, the study proposes a bi-directional grading method subdivided to horizontal and vertical direction. The grading rule allocating system suggested the size increments which improve the fitness of uniform. Using the 5th Size Korea data, the crosstabulation was conducted with 1305 females in the age group 20 49 years, and the size increments including 155 165 of height section and 79 94 of bust section, was selected for easy-order system. Also, the bi-directional grading method subdivided in horizontal and vertical direction was followed by factor analysis based on the circumference and height. And the grading rules were calculated by regression analysis.
\end{abstract}

Key words: Easy-order, Mass customization, Uniform, Grading, Regression coefficient; 이지오더, 매스 커스터마이제이션, 유니폼, 그레이딩, 회귀계수

\section{Introduction}

Corresponding author

E-mail: yunja@snu.ac.kr

This work was supported by the Technology Infrastructure Foundation Program funded by the ministry of Knowledge Economy, Republic of Korea.
Since the Industrial Revolution, a lot of manufacturers have focused on lowering costs to achieve economies of scale through mass production. However, as the market is getting advanced, the demand on an individual product and service became unstable 
so that manufacturers need customization to make customers satisfied. Till now manufacturers have avoided the customization, since they believed that it increases costs and could not give up economies of scale gained through mass production. However, as mass customization that can achieve customized product without cost increase was introduced in the 1990's, manufacturers have become able to pursue customization without cost increase (Lee \& Yoo, 2000).

According to the international trends of mass customization, it is introduced as the Made-to-Measure (MTM) method with which a cloth is manufactured to meet individual tastes and body shapes in the U.S.A. It is spreading over the menswear market as a method that fulfills demand for personality in the perspective of consumers. In Japan, there is the easyorder system as a method to solve professional labor shortage. Japan lacked professional labors in charge of tailored clothing because of devaluation of the manufacturing jobs by the youth, although there have been a luxury tendency of consumption demand since 1980 's. Accordingly, the demand on easy-order has been increased (Kim, 1999)

Most of the MTMs and the easy-order systems operated in the U.S.A. and European countries use 3dimensional measurement technology and automated sewing process and position in the higher valueadded industry with image marketing about the advanced technology. In particular, ARMEE21 of the Swiss army manufactures uniform with a digital method for the first time in the world by using 3D body scanners and Xfit Army system (Human Solution Inc.). This system covers whole manufacturing process from automatic size measurement to uniform delivery (juststyle, 2006). The easy-order system of Korean mainly targets men's suits and limits the number of measurements. Thus, it is difficult to say that it perfectly satisfies all kinds of customers' body shapes.

Since the IMF restructuring in Korea, the uniform industry has increasing demand on new uniform for the purpose of promoting corporate mood and a sense of unity. Recently, the demand on uniform is continuously increasing as the service leisure industry expands rapidly. However, studies about uniform by now have been limited to uniform design and sat- isfaction (Kim \& Park, 2002; Nam et al., 1997) rather than uniform manufacturing. Moreover, uniform is the item which is frequently worn, its fit takes important role of promoting corporate image as well as the efficiency of work, but it is hard to find the research on development of size system for uniform.

Since uniform is manufactured as mass production, individual body shapes cannot be reflected. Also, the body shapes should be classified in order to improve a cover rate. However, the easy-order system can reflect consumers' size through its unique production system similar to individual customization. Also, it is advantageous as a consumer's repurchase is naturally guaranteed considering the property of uniform that people should wear on continuously. In particular, the easy-order system should make clothes appropriate for each size although the fitting and adjusting process of a customized cloth is omitted. Thus, an effective size positioning system is required to reflect consumers' various body shapes for high productivity. Grading is the manufacturing process of developing a garment pattern in a range of sizes. Pattern alteration by grading principal is the most practical method for adapting a pattern to a consumer's body. So that, it is suggested as an approach to provide fit for mass customization (Ashdown \& Dunne, 2006; Schofield \& LaBat, 2005).

Therefore, the study suggests a grading rule allocating system that can improve the appropriateness of clothing for uniform easy-order system. Also, the study proposes a bi-directional grading method subdivided to horizontal and vertical direction. This grading method will allow manufacturing the clothing items that is repeatedly worn and purchased such as uniform, which has appropriate fit to size of consumers' body.

\section{Methods}

\section{Material}

For the study, the measurement data of 1305 females in the age group 20 49 years were selected from database of the 5th Size Korea (Korean Agency for Technology and Standards, 2004). A total of 21 measurements were used to statistical analysis. These 
included 5 heights, 5 circumferences, 10 lengths, and 1 width measurement, which are reference size for manufacturing an upper garment. The measurements used for analysis are shown at <Table 1>.

\section{Size Positioning for Easy-order}

The bust circumference and stature were categorized on the basis of KS clothing size standard. The size categories had deviation as $3 \mathrm{~cm}$ for bust circumference and $5 \mathrm{~cm}$ for stature. Each size category of bust circumference covers an indicated body size within $\pm 1.5 \mathrm{~cm}$ and stature within $\pm 2.5 \mathrm{~cm}$. The categorized size increments were classified by crosstabulation analysis. And size combinations with more than $2 \%$ of frequency were set as high-frequent size distribution (Kim, 1999) for easy-order system.

\section{Grading Principal}

A factor analysis was carried out in order to reduce the number of variables and to detect the structure in the relationships between variables. The number of the factor clarified the contents of the factor through orthogonal rotation by the Varimax method about the factors over eigenvalue 1.00 of Kaiser. The criteria to sort grading items to vertical and horizontal directions were adopted from factor analysis results. Grading rules were calculated by the result of regression analysis. For the statistical analysis, SPSSWIN 12.0 (SPSS Inc.) was utilized.

\section{Results}

\section{Setting of Optimum Size Increments}

Based on KS standard of adult women's size, the size increments of bust circumference and stature was analyzed with crosstabulation analysis method. Size combinations with more than $2 \%$ of frequency were set as high-frequent size distribution (Kim, 1999).

Using the crosstablulation analysis, the 15 size

Table 1. Profiles and statistics of measurements

(unit: $\mathrm{mm}$ )

\begin{tabular}{|c|c|c|c|c|c|c|c|}
\hline \multirow{2}{*}{\multicolumn{2}{|c|}{ Items }} & \multicolumn{2}{|c|}{$\begin{array}{c}\text { Age } 20 \sim 29 \\
(n=518)\end{array}$} & \multicolumn{2}{|c|}{$\begin{array}{c}\text { Age } 30 \sim 39 \\
(n=523)\end{array}$} & \multicolumn{2}{|c|}{$\begin{array}{c}\text { Age } 40 \sim 49 \\
(n=265)\end{array}$} \\
\hline & & mean & S.D. & mean & S.D. & mean & S.D. \\
\hline \multirow{5}{*}{ Height } & Stature & 1603 & 53.16 & 1583 & 50.23 & 1567 & 50.65 \\
\hline & Cervical height & 1350 & 48.55 & 1335 & 46.19 & 1321 & 46.83 \\
\hline & Axilla height & 1197 & 46.49 & 1177 & 42.61 & 1165 & 43.75 \\
\hline & Waist height & 996 & 41.31 & 975 & 40.63 & 959 & 41.06 \\
\hline & Hip height & 778 & 35.31 & 758 & 33.88 & 747 & 34.19 \\
\hline \multirow{5}{*}{ Circumference } & Neckbase circumference & 370 & 28.17 & 378 & 26.88 & 380 & 27.98 \\
\hline & Bust circumference & 858 & 58.22 & 897 & 73.21 & 916 & 68.76 \\
\hline & Waist circumference & 700 & 63.16 & 756 & 83.35 & 785 & 76.02 \\
\hline & Hip circumference & 929 & 51.54 & 941 & 54.87 & 937 & 51.70 \\
\hline & Upper arm circumference & 300 & 32.45 & 317 & 36.19 & 336 & 33.93 \\
\hline \multirow{10}{*}{ Length } & Neck shoulder point to bust point & 251 & 18.16 & 257 & 21.35 & 268 & 21.20 \\
\hline & Center front to bust point & 77 & 6.49 & 78 & 7.01 & 78 & 6.87 \\
\hline & Scye depth & 171 & 12.86 & 176 & 12.87 & 177 & 12.82 \\
\hline & Waist back length & 378 & 20.05 & 386 & 21.30 & 389 & 21.56 \\
\hline & Waist to hip length & 221 & 19.45 & 219 & 18.95 & 213 & 21.95 \\
\hline & Arm length & 515 & 23.06 & 505 & 23.06 & 502 & 22.18 \\
\hline & Upperarm length & 293 & 14.12 & 290 & 14.33 & 286 & 13.54 \\
\hline & Posterior shoulder length & 394 & 23.22 & 397 & 21.32 & 394 & 20.82 \\
\hline & Front interscye & 339 & 16.95 & 341 & 18.71 & 337 & 17.53 \\
\hline & Back interscye & 365 & 21.33 & 370 & 21.56 & 374 & 20.22 \\
\hline Width & Neck base width & 115 & 9.67 & 118 & 8.71 & 118 & 9.08 \\
\hline
\end{tabular}


increments were selected as the high frequency and were shown a cover rate of $63.68 \%$ in the total subjective groups (Table 2). Although the size positioning could cause too many sizes which decreases the productivity, these size increments are necessary for increasing fitness of uniform which is frequently worn. Also, uniform is expected to be purchased continuously, thus the decrease in productivity due to diversification of size is lower than other clothing items.

The size increments in <Table 2>, bust circumference and stature not vary in the same direction, they are independently act as 82-165 (bust circumferencestature), 91-165, 94-155. To manufacture these various sizes, the solution that overcomes the existing linear grading is needed. Therefore, the study suggests the bi-directional grading method subdivided to horizontal and vertical directions for grading various sizes composed by bust circumference and stature.

\section{Grading Sources}

The grading points were collected from representative pattern books and 4 apparel industries. The results shows that grading points related to circumferences were included neck width, neck depth, shoulder length, neck shoulder point to bust point, center front to bust point, mid armhole, armscye width, and upper sleeve width as shown at <Table 3>. The height related items for application of a grading rule are armscye depth, side length, center back, and sleeve length (Table 4). The back neck depth and front neck depth items are sometimes not be graded, while grading of waist back length is also often conducted once in the level of scye depth. In grading for height related items, previous studies did not put specific size increments, but suggested it proportionate to deviation of circumference related items (Price \& Zamkoff, 1996; Uh, 2005) or selected it based on a ratio of drawing formulas in the size table of original drawing (Secoli, 1999). U.S. anthropometric researchers O'Brien and Shelton (1941) found that height did not correlate with width measurements and they recommended separate sets of size charts for women of three different heights, which would provide many more size options.

Women's apparel companies had a grading tendency different from actual size labeling. Even in the

Table 2. Result of crosstabulation

(unit: number)

\begin{tabular}{c|c|c|c|c|c|c|c|c|c|c}
\hline \hline Stature & 140 & 145 & 150 & 155 & 160 & 165 & 170 & 175 & 180 & Total \\
\hline 70 & 0 & 0 & 1 & 0 & 0 & 0 & 0 & 0 & 0 & 1 \\
\hline 73 & 0 & 0 & 1 & 2 & 1 & 0 & 0 & 0 & 0 & 4 \\
\hline 76 & 0 & 0 & 3 & 15 & 8 & 3 & 0 & 0 & 0 & 29 \\
\hline 79 & 0 & 1 & 15 & 24 & 34 & 19 & 4 & 0 & 0 & 97 \\
\hline 82 & 0 & 2 & 16 & 49 & 70 & 36 & 13 & 0 & 0 & 186 \\
\hline 85 & 0 & 3 & 22 & 69 & 92 & 48 & 13 & 1 & 0 & 248 \\
\hline 88 & 0 & 2 & 21 & 67 & 70 & 44 & 16 & 0 & 1 & 221 \\
\hline 91 & 0 & 0 & 18 & 68 & 52 & 36 & 13 & 1 & 0 & 188 \\
\hline 94 & 1 & 0 & 14 & 34 & 62 & 14 & 5 & 0 & 0 & 130 \\
\hline 97 & 0 & 1 & 14 & 20 & 26 & 16 & 6 & 1 & 0 & 84 \\
\hline 100 & 0 & 1 & 5 & 17 & 14 & 8 & 3 & 0 & 0 & 48 \\
\hline 103 & 0 & 3 & 2 & 5 & 9 & 9 & 1 & 0 & 0 & 29 \\
\hline 106 & 0 & 0 & 3 & 12 & 7 & 4 & 0 & 0 & 0 & 26 \\
\hline 109 & 0 & 0 & 1 & 1 & 2 & 2 & 0 & 0 & 0 & 6 \\
\hline 112 & 0 & 0 & 1 & 1 & 1 & 3 & 0 & 0 & 0 & 6 \\
\hline 118 & 0 & 0 & 0 & 1 & 1 & 0 & 0 & 0 & 0 & 2 \\
\hline Total & 1 & 13 & 137 & 385 & 449 & 242 & 74 & 3 & 1 & 1305 \\
\hline
\end{tabular}


Table 3. Horizontal grading rules

( $3 \mathrm{~cm}$ interval, unit: $\mathrm{mm})$

\begin{tabular}{c|c|c|c|c|c|c|c}
\hline \hline Grading rule & $\begin{array}{c}\text { Price \& } \\
\text { Zamkoff } \\
\text { Dimension }\end{array}$ & $\begin{array}{c}\text { Secoli } \\
(1999)\end{array}$ & $\begin{array}{c}\text { Uh } \\
(2005)\end{array}$ & $\begin{array}{c}\text { Industry } \\
1\end{array}$ & $\begin{array}{c}\text { Industry } \\
2\end{array}$ & $\begin{array}{c}\text { Industry } \\
3\end{array}$ & $\begin{array}{c}\text { Industry } \\
4\end{array}$ \\
\hline Back neck width & 2.50 & 1.50 & 1.88 & 1.80 & 1.17 & 1.25 & 1.80 \\
\hline Front neck width & 2.50 & 1.50 & 1.88 & 1.80 & 1.17 & 1.25 & 1.80 \\
\hline Back neck depth & 2.50 & - & 1.50 & - & 0.94 & - \\
\hline Front neck depth & 2.50 & 1.00 & 1.50 & - & 0.94 & 1.25 & 1.25 \\
\hline Shoulder length & 2.50 & 3.00 & 1.50 & 2.00 & 3.52 & 1.25 & 2.00 \\
\hline Neck shoulder point to bust point & 5.00 & 10.63 & 3.75 & 2.25 & 3.75 & 4.70 & 4.75 \\
\hline Center front to bust point & 2.50 & 1.69 & 3.75 & 1.80 & 1.17 & 1.25 & 1.80 \\
\hline Across back & 3.75 & 6.00 & 3.75 & 3.80 & 4.69 & 3.75 & 3.75 \\
\hline Across chest & 3.75 & 6.00 & 3.75 & 3.80 & 4.69 & 3.75 & 3.75 \\
\hline Back armscye width & 3.75 & 1.50 & 3.75 & 3.70 & 2.81 & 3.75 & 3.75 \\
\hline Front armscye width & 3.75 & 1.50 & 3.75 & 3.70 & 2.81 & 3.75 & 3.75 \\
\hline Upper sleeve width & 10.03 & 8.30 & 11.25 & 12.06 & 12.90 & 12.25 & 12.25 \\
\hline
\end{tabular}

Table 4. Vertical grading rules

(5cm interval, unit: $\mathrm{mm}$ )

\begin{tabular}{c|c|c|c|c|c|c|c}
\hline \hline Grading rule & $\begin{array}{c}\text { Price \& } \\
\text { Zamkoff } \\
\text { Dimension }\end{array}$ & $\begin{array}{c}\text { Secoli } \\
(1999)\end{array}$ & $\begin{array}{c}\text { Uh } \\
(2005)\end{array}$ & $\begin{array}{c}\text { Industry } \\
1\end{array}$ & $\begin{array}{c}\text { Industry } \\
2\end{array}$ & $\begin{array}{c}\text { Industry } \\
3\end{array}$ & $\begin{array}{c}\text { Industry } \\
4\end{array}$ \\
\hline Armscye depth & 3.18 & 6.25 & 5.00 & 2.75 & 3.75 & 5.00 & 3.75 \\
\hline Side length & 3.18 & 6.25 & 3.00 & - & - & - & - \\
\hline Nape to waist & 6.35 & 12.50 & 8.00 & 2.75 & 3.75 & 5.00 & 3.75 \\
\hline Sleeve length & 9.53 & 18.13 & 10.00 & 25.20 & 23.50 & 24.00 & 22.83 \\
\hline
\end{tabular}

same size of stature, the length was graded. Or, a grading rule seems so little despite a $5 \mathrm{~cm}$ deviation of stature. For example, in grading between 82-91$160,85-94-160$, and 88-97-165 sizes, the rule for waist back length was $5 \mathrm{~mm}$ constantly. This means that the $5 \mathrm{~cm}$ deviation of stature was reflected in the entire grading process for the 3 sizes, separately their size label. Such grading rule can be one of the ways to satisfy various consumers' body shapes in the ready-to-wear market. However, it is not appropriate for the easy-order system that minimizes fitting and adjusting processes and maximizes reflection of consumers' body size. Therefore, the length and circumference grading rules should be separated to reflect size increments as in the rule of the study. Also, reflecting actual deviation can reflect consumers' sizes in the easy-order system.

\section{Measurements Categorizing}

A factor analysis was conducted with 15 measure- ments of a bust, which are required for clothing pattern system of an upper garment and drew 3 factors including circumference, height, and shoulder factors. After varimax rotation, the Eigen values of all the 3 factors became more than 1, of which cumulative variance value was $80.41 \%$. Factor 1 height related measurements; Factor 2 included circumference measurements related to obesity; Factor 3 included measurements related to shoulder width (Table 5).

The general size grading is conducted with fixed grading variation of circumference and height simultaneously. Even though this grading reflects the existing size of ready-to-wear clothing, it is hard to satisfy all the sizes in easy-order system which is comprised of various sizes. Therefore, the study subdivided the grading variation to horizontal and vertical direction according to the result of factor analysis. The Circumference factor is defined as horizontal direction, the interscye-back and posterior shoulder length are integrated as horizontal direction 
Table 5. Rotated component matrix

\begin{tabular}{c|c|c|c|c}
\hline \hline \multirow{3}{*}{ Factor } & \multirow{3}{|c}{ Items } & \multicolumn{3}{|c}{ Item Loadings } \\
\cline { 2 - 4 } & & 1 & 2 & 3 \\
\hline \multirow{4}{*}{ Height } & Axilla height & 0.965 & 0.015 & 0.049 \\
\cline { 2 - 5 } & Stature & 0.965 & 0.042 & 0.127 \\
\cline { 2 - 5 } & Cervical height & 0.960 & 0.080 & 0.150 \\
\cline { 2 - 5 } & Waist height & 0.955 & -0.047 & 0.036 \\
\cline { 2 - 5 } & Hip height & 0.935 & 0.006 & 0.038 \\
\hline \multirow{5}{*}{ Circumference } & Arm length & 0.864 & 0.072 & 0.043 \\
\cline { 2 - 5 } & Bust circumference & -0.097 & 0.880 & 0.341 \\
\cline { 2 - 5 } & Waist circumference & -0.157 & 0.821 & 0.415 \\
\cline { 2 - 5 } & Bust point to bust point & 0.071 & 0.809 & -0.198 \\
\cline { 2 - 5 } & Hip circumference & 0.178 & 0.748 & 0.352 \\
\cline { 2 - 5 } & Interscye-Front & 0.313 & 0.705 & 0.027 \\
\hline \multirow{5}{*}{ Shoulder } & Neck shoulder point to bust point & -0.046 & 0.696 & 0.318 \\
\cline { 2 - 5 } & Upper arm circumference & -0.174 & 0.623 & 0.559 \\
\cline { 2 - 5 } & Interscye-Back & 0.137 & 0.279 & 0.872 \\
\hline
\end{tabular}

since they are linked with the items which is included in circumference factor during grading. Also stature, cervical height, axilla height, waist height, hip height are abstracted as height factor, waist back length, and scye depth which are measured from those factors are defined as vertical direction.

\section{Development Grading Rule by Regression Analysis}

According to the factor analysis, the regression analysis was conducted with stature and bust circumference as independent variables for each vertical and horizontal dimension. For the regression analysis, the age groups were classified as 20 s, 30s and 40s. The constant term was eliminated due to the proportion between body measurements, and $\beta$-values on dependent variables in the regression analysis are on $\langle$ Table 6$\rangle$. All of the regression analysis shows that there was a significant effect $(p<.000)$, and the value of $\mathrm{R}^{2}$ is more than 0.99 . Thus, this indicates the explanatory power of height on vertical direction item and of bust circumference horizontal direction item is high.

The grading part of the clothing pattern is determined as the result of prior research $\langle$ Table 3$\rangle-<$ Table
4>, and classified into primary and secondary dimensions (Table 7)-(Table 8). The grading rules were extracted by each age group. The primary dimension is the same as the one on body measurement which abstracted by the $\beta$-value. And for the Across back and front, the average values were used to maintain. The secondary dimension for the grading of clothing was derived from the primary dimension. The method of detailed derivation of the secondary dimension is on $\langle$ Table 7$\rangle-\langle$ Table 8$\rangle$. Since the clothing pattern is base on the symmetry of human body, most of the pattern targets the half of human body from center front to center back. Therefore, the grading rule was derived from the half of a body on item of horizontal direction, except for upper arm circumference and neck shoulder point to bust point. The measurements of grading rule of vertical direction, upper arm circumference, and neck shoulder point to bust point were substituted as the same body measurement. The grading rule was base on $3 \mathrm{~cm}$ of bust circumference and $5 \mathrm{~cm}$ of stature variation as the size increments.

The application of the grading rule based on the regression analysis and the bi-directional grading method subdivided to horizontal and vertical direction for grading are shown on $\langle$ Fig. 1$\rangle-\langle$ Fig. 2$\rangle$. The grading rule which is developed by this study was derived 
Table 6. Regression equations of body measurements

\begin{tabular}{|c|c|c|c|c|c|c|c|c|c|c|}
\hline \multirow{2}{*}{ Dependent variables } & \multirow{2}{*}{$\begin{array}{c}\text { Independent } \\
\text { variables }\end{array}$} & \multicolumn{3}{|c|}{ Age $20 \sim 29$} & \multicolumn{3}{|c|}{ Age 30 39 } & \multicolumn{3}{|c|}{ Age $40 \sim 49$} \\
\hline & & $\beta$ & $\mathrm{R}^{2}$ & p-Value & $\beta$ & $\mathrm{R}^{2}$ & $\mathrm{p}$-Value & $\beta$ & $\mathrm{R}^{2}$ & p-Value \\
\hline Neck base width & Bust C. & 0.134 & 0.991 & 0.000 & 0.131 & 0.993 & 0.000 & 0.128 & 0.992 & 0.000 \\
\hline Neck C. & Bust C. & 0.367 & 0.997 & 0.000 & 0.366 & 0.996 & 0.000 & 0.357 & 0.996 & 0.000 \\
\hline Interscye-Front & Bust C. & 0.394 & 0.997 & 0.000 & 0.379 & 0.996 & 0.000 & 0.367 & 0.996 & 0.000 \\
\hline Interscye-Back & Bust C. & 0.425 & 0.996 & 0.000 & 0.411 & 0.995 & 0.000 & 0.407 & 0.996 & 0.000 \\
\hline Neck shoulder point to bust point & Bust C. & 0.293 & 0.996 & 0.000 & 0.286 & 0.997 & 0.000 & 0.292 & 0.995 & 0.000 \\
\hline Bust point to bust point & Bust C. & 0.180 & 0.995 & 0.000 & 0.175 & 0.995 & 0.000 & 0.169 & 0.994 & 0.000 \\
\hline Upper arm C. & Bust C. & 0.350 & 0.994 & 0.000 & 0.353 & 0.995 & 0.000 & 0.367 & 0.995 & 0.000 \\
\hline Wrist C. & Bust C. & 0.176 & 0.975 & 0.000 & 0.174 & 0.989 & 0.000 & 0.169 & 0.948 & 0.000 \\
\hline Scye depth & Stature & 0.107 & 0.994 & 0.000 & 0.111 & 0.995 & 0.000 & 0.113 & 0.995 & 0.000 \\
\hline Waist back length & Stature & 0.236 & 0.998 & 0.000 & 0.243 & 0.997 & 0.000 & 0.248 & 0.997 & 0.000 \\
\hline Waist to hip length & Stature & 0.138 & 0.994 & 0.000 & 0.138 & 0.994 & 0.000 & 0.136 & 0.991 & 0.000 \\
\hline Arm length & Stature & 0.321 & 0.999 & 0.000 & 0.319 & 0.999 & 0.000 & 0.321 & 0.999 & 0.000 \\
\hline Upperarm length & Stature & 0.183 & 0.999 & 0.000 & 0.183 & 0.999 & 0.000 & 0.183 & 0.999 & 0.000 \\
\hline
\end{tabular}

Table 7. Horizontal grading rule

( $3 \mathrm{~cm}$ of bust interval, unit: $\mathrm{mm}$ )

\begin{tabular}{|c|c|c|c|c|c|c|}
\hline & \multirow{2}{*}{\multicolumn{2}{|c|}{ Grade dimension }} & \multirow[b]{2}{*}{ Reference } & \multicolumn{3}{|c|}{ Rule } \\
\hline & & & & Age & Age & Age \\
\hline \multirow{10}{*}{$\begin{array}{l}\text { Primary } \\
\text { dimension }\end{array}$} & $\mathrm{A}$ & Total back & \multirow{2}{*}{$1 / 4$ of size interval } & 7.50 & 7.50 & 7.50 \\
\hline & $\mathrm{B}$ & Total front & & 7.50 & 7.50 & 7.50 \\
\hline & $\mathrm{C}$ & Across back & \multirow{2}{*}{ Average of front/back interscye } & 6.14 & 5.93 & 5.81 \\
\hline & $\mathrm{D}$ & Across front & & 6.14 & 5.93 & 5.81 \\
\hline & $\mathrm{E}$ & \multicolumn{2}{|c|}{ Neck shoulder point to bust point } & 8.79 & 8.58 & 8.76 \\
\hline & $\mathrm{F}$ & Center front to bust point & Bust point to bust point & 2.70 & 2.63 & 2.54 \\
\hline & $\mathrm{G}$ & Back neck width & \multirow{2}{*}{ Neck base width } & 2.01 & 1.97 & 1.92 \\
\hline & $\mathrm{H}$ & Front neck width & & 2.01 & 1.97 & 1.92 \\
\hline & $\mathrm{I}$ & Upper sleeve width & Upper arm C. & 10.50 & 10.59 & 11.01 \\
\hline & $\mathrm{J}$ & Sleeve opening & Wrist C. & 5.28 & 5.22 & 5.07 \\
\hline \multirow{3}{*}{$\begin{array}{l}\text { Secondary } \\
\text { dimension }\end{array}$} & $\mathrm{K}$ & Back armscye width & \multirow{2}{*}{ Total front-Across back } & 1.36 & 1.58 & 7.50 \\
\hline & $\mathrm{L}$ & Front armscye width & & 1.36 & 1.58 & 7.50 \\
\hline & $\mathrm{M}$ & Front neck depth & Neck base width & 2.01 & 1.97 & 1.92 \\
\hline
\end{tabular}

Table 8. Vertical grading rule

( $5 \mathrm{~cm}$ of stature interval, unit; $\mathrm{mm})$

\begin{tabular}{|c|c|c|c|c|c|c|}
\hline & \multirow{2}{*}{\multicolumn{2}{|c|}{ Grade dimension }} & \multirow[b]{2}{*}{ Reference } & \multicolumn{3}{|c|}{ Rule } \\
\hline & & & & $\begin{array}{c}\text { Age } \\
20 \sim 29\end{array}$ & $\begin{array}{c}\text { Age } \\
30 \sim 39\end{array}$ & $\begin{array}{c}\text { Age } \\
40 \sim 49\end{array}$ \\
\hline \multirow{4}{*}{$\begin{array}{c}\text { Primary } \\
\text { dimension }\end{array}$} & $\mathrm{N}$ & Armscye depth & Scye depth & 5.35 & 5.55 & 5.65 \\
\hline & $\mathrm{O}$ & Center back & Waist back length & 11.80 & 12.15 & 12.40 \\
\hline & $\mathrm{P}$ & Hip length & Waist to hip length & 6.90 & 6.90 & 6.80 \\
\hline & Q & Sleeve length & Arm length & 16.05 & 15.95 & 16.05 \\
\hline $\begin{array}{l}\text { Secondary } \\
\text { dimension }\end{array}$ & $\mathrm{R}$ & Sleeve cap height & $2 / 3$ of armscye depth & 3.57 & 3.70 & 3.77 \\
\hline
\end{tabular}




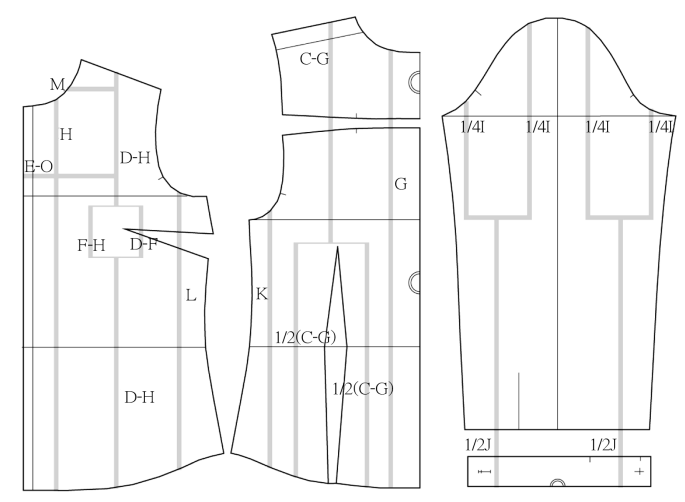

Fig. 1. Horizontal grading.

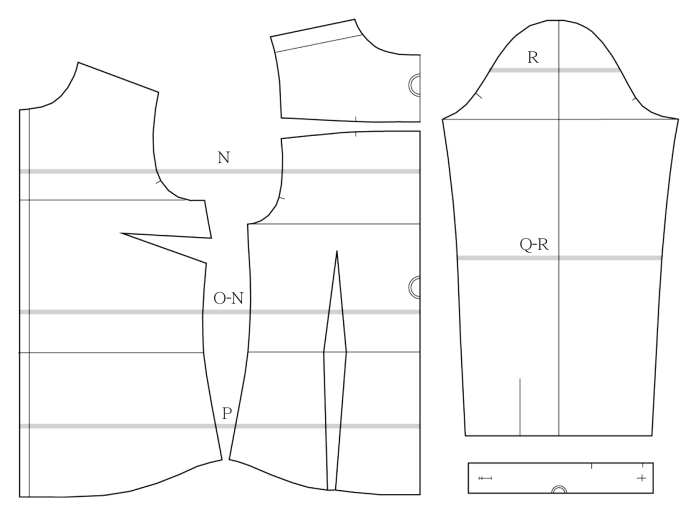

Fig. 2. Horizontal grading.

from the regression analysis based on the body measurement, is different with the grading rule on $<$ Table 3>-<Table 4>. However, it suggests the bi-directional grading method subdivided to horizontal and vertical direction for grading, and covers various size combinations, and is meaningful suggestion that the grading rule can be made with the proportion of the body measurement.

\section{Conclusions}

To provide adequate fit for women over a range of sizes, the grading process should reflect their body dimensions. Current methods of creating sized garments are not addressing the need for a good or even an adequate fit for the easy-order system. So, this study suggested the bi-directional method to change a pattern for each measurements. The grading rule was dualized for horizontal and vertical directions.

This study developed the grading rule allocating system covering various body size based on stature and bust circumference, which are important body measurements and show the volume of body. This grading rule allocating system suggested the size increments which improve the fitness of uniform. Using the 5th Size Korea data, the crosstabulation was conducted with 1305 females in the age group 20 49 years, and the size increments including 155 165 of height section and 79 94 of bust section, was selected for easy-order system. Also, the method that can be altered according to the size increments and the bi-directional grading method subdivided to horizontal and vertical direction for grading were suggested, and the study classified detailed item followed by factor analysis base on the circumference and height. With the consequence of the result, the study conducted regression analysis on expectation of detailed body measurement with stature and bust circumference as independent variables, and suggests grading rule using the $\beta$-value.

This suggestion of bi-directional grading method got over the existing linear size system, enables the development of various sizes, and will improve the fitness of products targeted to consumer with various body shapes. Also, the grading rule by regression analysis based on body measurement will reflect properties of each body part according to sizes. This study suggests grading rules for each age group. For uniform production, separated grading for age group mat not be easy to use, but could be useful depends on the age of target market.

The pattern grading, however, is the process of enlargement and reduction without alteration of silhouette of master pattern based on measurement system (Cho, 1999). The study only suggests the grading rule which is simply in proportion to the body measurement, and it will be difficult to maintain the proportion of the clothing. In addition, the clothing ease for movement wasn't considered since the result was based on the body measurement in comfortable posture. Therefore, the research on the grading rule which considers the clothing ease for movement should be conducted according to the size fluctuation with main- 
taining the master pattern. In addition, this research couldn't present verification about improvement of uniform fitness since the proposed grading rule allocating system stays as an experimental methodology. Once the proposed grading rule in this study is validated in practice, it is expected that the proposed method enables uniform manufacturers to gain enhanced garment fitness.

\section{References}

Ashdown, S. P., \& Dunne, L. (2006). A study of automated custom fit: Readiness of the technology for the apparel industry. Clothing and Textiles Research Journal, 24(2), 121-136.

Cheon, J. S., \& Im, H. S. (2003). A study on the use of MTM CAD program for mass customization of men's suit. The Research Journal of the Costume Culture, 11(5), 647-656.

Cho, Y. (1999). Pattern grading. Seoul: Kyohaksa.

istituto carlo secoli. (1999). modellistica industriale donna. Milano: istituto carlo secoli.

just-style. (2006, June 12). Army uniforms to be measured digitally. just-style. Retrieved October 6, 2006, from http://www.just-style.com.

Kim, K. J. (1999). Designation of bodytypes and size specifications for designing of the ready-made jacket 36 years to 43 on the Korean adult males-. Journal of the Korean Society of Clothing and textiles, 23(8), 12401247.
Kim, M. J., \& Park, J. H. (2002). Soccer uniform designs representing Korean image. Journal of the Korean Society of Costume, 52(4), 125-139.

Kim, N. H. (1999). The comparative study of men's customsuits, systemorder, and ready-made suits: Centering around choice of information source, risk perception and benefit sought. Master's thesis Sungkyunkwan University, Seoul.

Korean Agency for Technology and Standards. (2004). Fifth Size Korea Technical Report. Seoul: The ministry of Knowledge Economy, Korean Agency for Technology and Standards.

Lee, S. C., \& Yoo, S. A. (2000). Strategies for the effective conduct of mass customization cases in Korean firms. The Korea Society of Management Information Systems, 2000(0), 297-306.

Nam, Y. J., Kim, K. I., \& Lee, Y. J. (1997). A survey on uniforms and development of design(1). Journal of the Korean Society of Clothing and textiles, 21(2), 455470.

O'Brien, R., \& Shelton, W. C. (1941). Women's measurements for garment and pattern construction. Washington, DC: US Government Printing Office.

Price, J., \& Zamkoff, B. (1996). Grading techniques for fashion design (2nd ed.). New York: Fairchild publication.

Schofield, N. A., \& LaBat, K. L. (2005). Defining and testing the assumptions used in current apparel grading practice. Clothing and Textiles Research Journal, 26(6), $135-150$.

Uh, M. K. (2005). Industrial pattern making. Seoul: Kyohaksa.

\section{요 약}

매스 커스터마이제이션 생산 방식이 국내외 의류산업에서 새로운 제조방식으로 확산되고 있다. 특히 국가별로 MTM, 이지오더(Easy-order) 등의 명칭으로 기성복에 소비자 체형을 반영하는 노력이 끊임없이 진행되고 있다. 유니폼은 지속적인 착용과 재구매가 예상되는 의류아이템이므로 이에 대한 사이즈 적용 이 필요하다. 따라서 본 연구에서는 국내 유니폼 생산에 이지오더 시스템 방식을 도입하기 위하기 위한 사이즈 포지셔닝 시스템을 제공하고 다양한 사이즈에 맞는 의복 패턴을 제작하기 위하여 양방향 그레이 딩 방식을 제안하였다. 연구결과로는 첫째, 5 차 사이즈코리아 측정치를 이용하여 키와 가슴둘레에 대한 교차분석을 실시하여 다빈도 구간을 유니폼 사이즈 구간으로 설정하였다. 둘째, 인체측정치에 대한 요인 분석을 실시하여 높이, 둘레, 어깨요인으로 분류하였으며 둘레와 어깨요인을 통합하여 높이와 둘레로 측 정항목을 이원화하였다. 셋째, 요인분석 결과로 이원화된 높이와 둘레항목을 각각 키와 젖가슴둘레를 독 립변수로 회귀분석을 실시하였으며 회귀계수를 활용한 그레이딩룰을 산출하였다. 